\title{
TRANS-
}

Revue de littérature générale et comparée

2017

L'Illisible

\section{Gender Matters: What Is at Stake in Dealing with Children's Literature?}

Giulia Zanfabro

revues.org

Publisher

Presses Sorbonne Nouvelle

Electronic version

URL: http://trans.revues.org/1440

DOI: $10.4000 /$ trans. 1440

ISSN: 1778-3887

Electronic reference

Giulia Zanfabro, « Gender Matters: What Is at Stake in Dealing with Children's Literature? », TRANS-

[Online], | 2017, Online since 02 March 2017, connection on 06 April 2017. URL : http://

trans.revues.org/1440

This text was automatically generated on 6 April 2017

Tous droits réservés 


\title{
Gender Matters: What Is at Stake in Dealing with Children's Literature?
}

\author{
Giulia Zanfabro
}

"È una possibilità" disse Sophie. E lo disse piano, perché gli altri non la sentissero. "Mai ignorare una possibilità"'.

Katherine Rundell, Sophie sui tetti di Parigi

\section{Introduction}

Childhood reading is mediated by adult tastes, interests, and preconceptions at all stages of the production, distribution, procurement, and consumption of reading material. It is no exaggeration to say that gender identity is acquired hand-in-hand with literacy ${ }^{3}$.

Despite the fact that "the representation of gendered bodies and behaviours" ${ }^{\text {" is an issue }}$ that is "highly significant" and "frequently addressed" 6 in children's literature, as Flanagan has claimed, "the application of gender studies to children's texts [...] is still very much a work in progress"'. While Anglophone children's literature criticism has at least acknowledged the need for gender studies ${ }^{8}$, in Italy the importance of gender issues has not yet really been discussed. Excluded by or marginalised from literary studies, Italian children's literature is central in education departments 9 . The negative prejudice that literary studies historically maintain against children's books in Italy ${ }^{10}$ makes this field of study particularly resistant to any literary approach ${ }^{11}$, including that of gender. In fact, analyses of gender issues and children's literature are mostly limited to the deconstruction of gender stereotypes and are usually aimed at furthering educational projects $^{12}$.Though they claim to be interested in the deconstruction of gender, such analyses tend to presuppose the binary opposition between men and women, focusing almost exclusively on women and assuming that what is at stake in dealing with gender is merely the subversion of gender models. On the contrary, the theoretical perspective I endorse implies a multifaceted and performative notion of gender, one which is not limited to the binary opposition between boys and girls and men and women, but is 
focused on how gender and gender identities are performatively constructed and produced within culture in its broader sense.

The article is grounded on the premise that children's literature is literature. If this should sound redundant to scholars working in Anglophone departments, actually it is not so with regard to Italian criticism. The framework for the analysis is provided by literary theory. It is quite telling that scholars working in the magmatic field of children's literature often feel the need to specify not only that children's literature is literature, but also that they do work within literary theory - a clarification which, as Thacker claims, someone studying Virginia Woolf ${ }^{13}$ is not required to provide. And yet, children's literature, understood in its cultural and transmedial dimension ${ }^{14}$, raises many of the questions ordinarily considered as pertaining to theory. Children's literature criticism is literary theory, if theory is, as Culler maintains : interdisciplinary (children's literature may be studied from different perspectives within different disciplines); analytical and speculative ("an attempt to work out what is involved in what we call sex or language or writing or meaning or subject"15: children's literature may question what we conceive as sex, as language, and as subject) ; "a critique of common sense"16 and an "enquiry into the categories we use in making sense of things, in literature and in other discursive practices 17"(children's literature may deconstruct the effects of naturalness, the categories we use to define literature, literary canon and childhood produce).

3 My main aims are, firstly, to argue the importance of children's literature as literature ${ }^{18}$, and secondly, to show why gender does matter within children's literature and its criticism, even within those books not tackling the issue at first glance.

\section{Dilemmas in Children's Literature : Performativity Matters}

4 Critics do not agree on the definition of children's literature, on what this definition should entail, on its object and even on the ontological status of its content. Nevertheless, they do agree on the constitutive role played by the ideas we have on the readership explicitly addressed by children's literature in shaping all discourses that focus on the category of books written, produced, marketed for children. As a category ${ }^{19}$, or as a field ${ }^{20}$, texts considered to be "children's literature ${ }^{21}$ " are not "only similar to each other but also similarly different from other forms of literature ${ }^{22}$." Hunger Games, La nonna in fuga, Rosaconfetto, La principessa e il drago, L'altra parte di me, Trevor, and Lunamay differ in length, topic, format, implied readership age, complexity, genre... and yet they all are part of the same category of books. Lesnik-Oberstein takes the existence of this category to depend absolutely "on supposed relationships with a particular reading audience : children ${ }^{23}$." Children (and childhood) as implied readership are what make it possible for children's literature to be defined as such.

The diversification of children's books from those for adults is merely instrumental and depends on some generic assumptions about childhood, literature and children's literature : both the categorisation and the diversification of these texts as children's literature are made visible by publishers by means of a series of paratextual elements such as book covers, inclusion in specific series, hints for the age of the readers, descriptions on the back cover, and so on. The distinction between a children's book and a book for adults is impossible within a system which does not mark a certain book's belonging to 
"children's literature" by means of such editorial devices. The effectiveness of this editorial criterion is particularly evident in cases of translation: as it crosses different linguistic contexts the same book may target children, young adults, adults and even both readerships at the same time ${ }^{24}$.

The existence of children's literature depends on and is defined by the existence of a global publishing market that produces it and markets it as such. Children's literature is, in this sense, an institution with its own economic, social and cultural reality ${ }^{25}$. There are at least three aspects concurring to determine what children's literature is ${ }^{26}:$ (1) economic aspects (publishers, prizes, research centres, scholars, publishing houses, the whole market targeting children); (2) ideological aspects (educational, political, and pedagogical norms historically defining what children's literature should be and what is should do); and (3) aesthetic aspects (aesthetic norms regulating what is historically conceived as "literary value" strongly depend on ideological, political and generally extra-literary phenomena). The institution of children's literature not only depends on these aspects, but creates the same practices defining it as such. Even if, in the perspective I endorse, all literature is involved in such processes of canonisation and institutionalisation, there is something different in children's literature. The institution of children's literature is in fact characterised by an irreducible asymmetry ${ }^{27}$ between adults, controlling all aspects that concern production and distribution, and children, to whom this literature is addressed. On the one hand, adults write, publish, choose, categorise, praise, give prizes, select what kind of literature children (should) read $^{28}$; on the other, children are excluded from all aspects related to the production ${ }^{29}$ of those books written and published for them

[...] with the idea that their main readers would be children or teenagers and the conviction that the youthfulness of these readers would influence what they might like to or be able to or need to read. The texts all address young readers in terms that make their youth a matter of significance ${ }^{30}$.

Children's literature readership is selected, created, determined by the ideas adults have of that specific readership and of its place within society. By selecting its readership, children's literature concurs to determine - performatively - the same readership it addresses to, and, by means of this appeal, creates the conditions for children's literature own existence.

Children's literature is, in this sense, a particular kind of culturally situated discursive practice. Defining childhood ${ }^{31}$ entails political issues. The matter is political not only because of the already mentioned asymmetry children's literature implies, but also because "the child, however problematically, represents the future, and perpetuating a given ideology necessitates that children inherit its value ${ }^{32}$."

Since childhood is usually conceived of as innocent and helpless, critics' main concern seems to be focused on the issue of "what is good for children ${ }^{33}$," where good means appropriate. Usually, the overt intention of adults who write, produce, market, discuss books for children is aimed at causing a positive response toward their own value system. Ultimately, children's literature teaches children "how to be child-like ${ }^{34}$."

10 McCallum $^{35}$ and Stephens ${ }^{36}$ have outlined the liberal humanist ideology children's literature presupposes. Child characters have strong, neat, autonomous identities and their self is usually represented as natural and authentic ; moreover, fictional children are perceived as free to act independently within and on the reality they inhabit: "the question in adolescent and children's fiction is not whether the subject exists, but what 
kind of subject it is and what are the conditions of its coming into being ${ }^{37}$." The presupposed liberal humanist ideology and adults' ideas on childhood imbricate children's literature criticism in a double-bind: children are considered free (from ideologies), independent and spontaneous human beings; on the other hand, adults are often worried about the effects this literature (and the kind of ideology it may entail) may have on its child readers, as if texts for children were not already imbricated in ideologies, or as if it weren't adults' concerns.

11 Most of children's literature criticism presupposes representationalism. The belief in political, linguistic, epistemological forms of representationalism is underlied by the metaphysical presupposition according to which beings exist as individuals with inherent attributes, anterior to their representation ${ }^{38}$. Karen Barad defines representationalism as

[...] the belief in the ontological distinction between representations and that which they purport to represent; in particular, that which is represented is held to be independent of all practices of representing ${ }^{39}$.

12 The representationlist logic presupposes the existence of a real child outside of the text and considers "good" those books which better represent that (real) child. On the contrary, the perspective endorsed in this essay implies a performative dimension to understand children's literature ${ }^{40}$. Within such a framework, "subjects and objects do not pre-exist as such ${ }^{41}$," but they emerge through processes of mattering. If we read children's literature through Barad, there is no given real child, but childhood comes to matter within specific processes of mattering.

In a representationalist framework, relevant questions concern identification; on the contrary, within a performative dimension, relevant questions concern "which differences matter, how they matter, and for whom" ${ }^{42}$. Barad's notion of performativity ${ }^{43}$ is particularly productive to question the representationalism often implied by children's literature critics and can be applied to argue the important role children's literature has in the definition of childhood narratives ${ }^{44}$, and the performative power these narratives have on the same childhood whose limits of materialization they concur to establish and upon which they produce effects of naturalness, origin and inevitability ${ }^{45}$.

In Butler's view, "performativity must be understood not as a singular deliberate "act", but, rather, as the reiterative and citational practice by which discourse produces the effects that it names ${ }^{46}$." Gender norms regulating gender and sex work performatively to construct the materiality of bodies and, specifically, as Butler claims, to materialize the sexual difference in order for heteronormativity to be reinforced. To claim that gender norms effect the materialization of bodies does not mean that gender, as a cultural construction, is simply attached on a pre-existing material surface, but that, "Once 'sex' itself is understood in its normativity, the materiality of the body will not be thinkable apart from the materialization of that regulatory norm ${ }^{47}$." The impossibility to think materiality apart from the norm regulating its materialization is particularly significant because the formation of the "I" strictly depends on the assumption of a given sex and of the relation between the assumption of a given sex with questions of identification and with "the discursive means by which the heterosexual imperative enables certain sexed identifications and forcloses and/or disavows other identifications ${ }^{48}$."

Once children's literature and gender matters are framed in these terms, significant questions to be addressed concern representation and representability: how are gender identities represented? How is gender produced and given within children's literature? What exclusions are enacted in this process of mattering? 


\section{Gender Dilemmas}

The impact of feminism on literary criticism over the past thirty-five years has been profound and wide-ranging. It has transformed the academic study of literary texts, fundamentally altering the canon of what is taught and setting a new agenda for analysis, as well as radically influencing the parallel processes of publishing, rewriting and literary reception ${ }^{49}$.

There is little agreement on what feminist theories are and on what they do ; however, despite all their different and not necessarily consistent approaches, feminist theories (if they succeed in considering gender and performativity in their wider sense) can provide a theoretical framework which can help us not to take anything for granted and to cast light not only on the exclusions that gender norms may produce, but also on all other normative exclusions and on the dilemmas "that invariably arise when individuals do not fit neatly into normative categories of existence ${ }^{50}$."

Children's literature, as it is conceived, represents strong conceptions of subject and provides its characters with a strong agency. The strong identities children's literature characters have is consistent with the kind of agency the liberal humanist ideology presupposes. Indeed, as Butler claims, "the constituted character of the subject is the very precondition of its agency ${ }^{51}$." However, what is actually at stake in dealing with children's literature is the constitutive element each identity formation entails and the exclusions that, in its constituting as such, may be originated or re-iterated: "identity categories are never merely descriptive, but always normative, and as such, exclusionary 52."

There is an ordinary sense in which gender dilemmas are a fundamental issue within children's literature : if children's literature teaches children how to be child-like, where to be child-like simply means to adhere to what a given culture considers to be "natural" for childhood ${ }^{53}$, then, gender norms are inevitably part of the education children's literature provides for its readers. Though, as Mallan claims, "children's literature is not a monolithic field that offers a singular 'voice', nor does it invite a singular scholarship of interpretation ${ }^{54}$, it certainly is part of the practices narrating childhood in certain ways ${ }^{55}$ and "it does make significant and often undervalued contributions to how its child readers see the world and their place in $i^{56}$."

It is precisely in the relation with gender issues that Nodelman identifies one of the main features of children's literature ${ }^{57}$ : to teach children how to be child-like means, in fact, to teach them "what it means for girls to be girls and boys to be boys ${ }^{58}$." Clark has contended that "From the start, children's literature was imbricated with material culture, and reading and play were seen through the lens of gender ${ }^{59}$." Children's literature is, indeed, one of the ways by which adults construct the categories of age and gender ${ }^{60}$, and they do it performatively. Gender is performatively constructed both within books for children (in characters, in language, in dialogues, in stories) and outside these books (in book covers, in the hints for the readers). Since gender is constructed performatively, it is always possible to deconstruct and to question the gender norms that make it possible for gender to materialize and the effects of naturalness, origin, inevitability they produce.

Gender normativity usually works so that boys and girls are understood as two distinct categories and it produces these categories so that they have specific and appropriate tastes, desires, behaviours. The choice to diversify what is thought to be girlish from what 
is thought to be boyish is a trend not only within the literary market system, but within the whole market targeting children and young adults. One only has to enter any bookstore, any toy shop or simply any children's clothing brand site to picture the kind of gender diversification I am talking about. Depending on which tastes, desires, behaviours adults acknowledge as appropriate for children, childhood is materialized within a specific power configuration. Childhood is, in this sense, an effect of power: the distinction between what is childhood and what is not is always normative. Childhood, however, is not a mere construction: discursive practices do not create childhood; on the contrary, childhood can materialize only within specific discursive practices and power dynamics. Childhood, then, materializes in a system of discourses, practices and norms that concur to determine what it means to be children. Children's literature is an integral part of these practices. Because of the fundamental role gender norms play in establishing who has the right to be acknowledged as a human being ${ }^{61}$, gender, understood in these performative terms, is a key aspect in the materialization of childhood, in what childhood is taken to be (in what it means for boys to be boys and for girls to be girls). To read children's literature through gender performativity means not only to question how gender is produced within and by language, but also, as Mallan claims, "how literary discourse provides us with a means to attend to what literary language 'does' as well as what it "says' ${ }^{\prime 2}$."

\section{Subversions, Agency Attributions, Desires : Non- normative Representations}

21 Children's books seem to engage with three different narrative strategies in order to question gender normativity: subversion, agency attribution, and representation of nonnormative desires.

In her introductory chapter on gender studies, Flanagan points out that "evidence of an ideological agenda that explicitly seeks to critique normative categories of gender does not automatically guarantee success ${ }^{63}$." Subversion narratives often exemplify this failure. Undoing gender means much more than simply applying to girls some behaviours that a binary logic usually conceives as naturally boyish- or vice versa. This kind of subversion, by marking some characters' behaviours as exceptionally non-normative, usually reconfirms the binarism implied in the construction of normative masculinity and of normative femininity.

However, subversion is the first and easiest strategy in order to question gender normativity. It does not seem a coincidence that books trying to question feminine normativity in such a way started to be published in the Seventies. Pasqualina's story, recently re-edited by Motta Junior, provides a perfect example. Rosaconfetto e altrestorie was published in 1976 by "Dalla parte delle bambine," a publishing house founded in 1974 by Adela Turin and Nella Bosnia with the aim of creating new images of femininity to be read by young girls. At that time, "Dalla parte delle bambine" thrilled all feminist parents in search of non-sexist and non-stereotyped books for their children ${ }^{64}$.In a world where all female elephants have big, bright eyes and pink skin ("rosa confetto ${ }^{65 ")}$ because their diet consists exclusively of peonies and anemones, Pasqualina's skin is not pink and will never be (Rosaconfetto e alter storie). In Pasqualina's world there are, on the one hand, pink female elephants living within an enclosure ; on the other, outside of it, "elephant grey" 
("grigio elefante ${ }^{66 ")}$ fathers, brothers, male cousins and male friends playing in the savannah, eating green grass, and rolling around in the mud. The "elephant grey" Pasqualina is the disgrace of her mother, who wants her to be as pink as she is; of her father, terrified by his daughter's inappropriate, rebellious personality ; and of the whole community, which sees her as different from all other female elephants. When Pasqualina gathers the courage to go beyond the enclosure she is forced in by norms and habits, at first, she arouses concern, then curiosity and, finally, all young female elephants timidly follow her outside the enclosure: "Da quell'epoca ormai lontana riesce difficile, a chi guardi giocare i piccoli di quelle tribù, decider quali sono le elefantine e quali gli elefantini ${ }^{67}$."

Published in the same years as Rosaconfetto, Extraterrestre alla pari ${ }^{68}$ stages, even more overtly, the same kind of dynamics. However, compared to Pasqualina's story, Mo's explicitly questions not only female stereotypes but also gender relations. Mo is an extraterrestrial just arrived on Earth from Daneb to live with a typical terrestrial family. Nobody knows whether Mo is a girl or a boy. On Daneb, nobody asks this awkward question before fifty. While this sexual indeterminacy does not seem to bother neither Mo, nor his/her parents, the impossibility to categorise Mo as a boy or as a girl makes humans crazy. Mo's terrestrial parents are challenged by the absolute absence of any evidence in structing them in how to behave appropriately:

Se non sappiamo se è maschio o femmina, in quale modo ci dovremmo comportare con lui ? O con lei ?... Insomma, con Mo, accidenti, qualunque cosa sia !69

Mo non era un essere ambiguo e inquietante, era certamente un bambino o una bambina e prestissimo lo si sarebbe saputo e ci si sarebbe potuti comportare di conseguenza ${ }^{70}$.

The young alien will experiment both life as a girl and life as a boy and the difference will be shockingly evident - for Mo and even more for contemporary readers. As a boy, Mo is expected to excel in science and mathematics and in all kinds of team play; he leads a group of boys, and is never asked where he is or to come home at a certain time. On the contrary, the education of the young Mo as a girl is described in all its normative restrictions. As a girl, Mo loses the freedom she had as a boy: she cannot do anything, and whenever she tries to disagree with something adults tell her, she is silenced. The only thing she can do - and she couldn't as a boy - is wear coloured clothes - and not only blue ones. Extraterrestre alla pari was undoubtedly revolutionary when it came out in the Seventies. Nonetheless, the constitutive limit of such an operation is that, by subverting gender norms, it reconfirms and reinforces the same norms it purports to subvert. Pitzorno's story is imbricated in binarism and the only open possibility seems to be given by the existence of another planet, Daneb, where sexual difference and gender identities are less normative than on Earth.

There are other and more nuanced examples of subversion in the contemporary Italian publishing market ${ }^{71}$. In a world where girls are expected to be, to desire to be and to behave as princesses, Olivia (Olivia e le principesse ${ }^{72}$ ), a little pig, does not want to hear of dressing as a princess. There are plenty of alternatives, she thinks : why can't she dress as a warthog? Not to mention the fact that she is rather ambitious and aims at being queen, certainly not princess.

Elizabeth (La principessa e il drago ${ }^{73}$ ), a real princess about to marry, is ready to take on the task of saving her prince kidnapped by a dragon. She saves him, and, in so doing, she subverts the narrative of the prince saving the princess. However, the prince turns out to 
be a spoilt and boring dandy and Elizabeth will not have the slightest intention to marry him. In La principessa e il drago the idea of subversion is overtly claimed even outside of the text, in the name Edizioni Giralangolo have chosen for the series in which the book is published : "Sottosopra" (upside down). The series is edited by Irene Biemmi and is aimed at fostering new and alternative ideas on gender, gender identities and gender relations in children's books. The main characters of these books are girls and boys, men and women, free to act, think and behave out of the limits gender norms establish on their biological sex ${ }^{74}$. La principessa e il drago is also part of a list edited by Liber* Tutt*, a project supported by the local administration of the Tuscany region and aimed at deconstructing gender stereotypes ${ }^{75}$.

Princess Magnolia (La principessa in black) is also a real princess. All pink and manners, she is repeatedly being told that princesses do not run ; do not dress in black; do not throw their clothes in the broom closet and, above all, "le principesse non sfrecciano giù per uno scivolo segreto e non superano con un balzo le mura del loro castello ${ }^{76}$." However, despite her strict education, the princess keeps a secret: she is the one who secretly dresses in black to protect her castle from the monsters.

Pasqualina, Mo and other female characters' gender is textually constructed and produced. The construction of their femininity is overtly non-normative. They all allude to the norm in order to subvert it: Pasqualina opposes feminine normativity when she exits the enclosure; the same is true of Magnolia, dressing in black and secretly refusing to be the pink and well-mannered princess she is supposed to be ; and, in a way, it is true even of Elizabeth who subverts the norms not only by saving her prince, but also by fiercely refusing to marry him. Mo's case is a little more complicated, since $\mathrm{s} / \mathrm{he}$ chooses to leave Earth and to go back on Daneb, when s/he will be free to be whatever s/he is.

Though this kind of subversion is undoubtedly significant and marks a change in the publishing market, I have already tried to point out how, by marking some characters' behaviours as exceptionally non-normative, subversion usually works to reinforce the binarism implied in the construction of normative masculinity and of normative femininity.

31 The second strategy, i.e. agency attribution, stands for another important change within children's literature. In a publishing market dominated by male central characters ${ }^{77}$ and where the only female protagonists are to be found in book series specifically targeting girls $^{78}$ - as if a female protagonist were not interesting enough for a male reader - there is, indeed, a change to be noticed in how girls and women are represented. Though there still exist book series for girls and novels in which normative femininity is produced and reiterated, contemporary children's fiction heroes are often strong, independent girls with a well-defined agency. Moreover, their stories are published and marketed as being both for girls and for boys.

32 Katnis (Hunger Games ${ }^{79}$ ), Tris (Divergent ${ }^{80}$ ) and Tally (Beauty ${ }^{81}$ ), protagonists of three different dystopian trilogies, can all be described in these terms. Their stories are quite similar: they all try to subvert the society in which they are born; they lead the revolution; they win and defeat those in power.

The Hunger Games are a televised event in which the participants are forced to fight to the death. Every year, one boy and one girl from each of the twelve districts of the dystopian, post-apocalyptic nation of Panem are selected by lottery to compete. The Games end when only one "tribute" survives. In the first book of the trilogy, Katnis voluntarily 
enters the competition in order to replace and save her younger sister; she proves her valour as warrior, archer, and strategist, and, finally, she succeeds in winning the fearsome Hunger Games using both her physical strength and her brain, refusing to kill her friend and forcing Capitol City to exceptionally accept both of them as the winners of the Games.

Trisalso lives in a non-specified dystopian future, where citizens are divided in five different factions. The rigid social structure is aimed at maintaining control and preventing wars. Tris is a Divergent, and, as such, does not fit into any of the factions. The girl, strong and clever like Katnis, has to conceal her "true nature" not to be discovered by the Erudite and Dauntless leaders in charge to control and maintain the status quo. Like Katnis, Tris opposes those in power and leads the insurgents in order to subvert social order.

Tally lives in a world in which, at the age of 16 , each teenager undergoes a surgery in order to become "pretty." The systematic division of the world in "uglies" and "pretties" is monitored by "specials" that succeed in keeping pretties under their control by means of the surgery that, in addition to perfect beauty, includes a small brain wound making all pretties alike. Tally undergoes surgery, but manages to heal the brain wound and joins the resistance.

Katnis, Tris, and Tally make it possible for a female agency to be represented and imagined in books to be read by both girls and boys. The remarkable attention editors are currently maintaining towards strong female characters within novels targeting a universal (non-gendered) readership can be well exemplified by the publication of a special double-feature book to celebrate the tenth anniversary of Twilight: on the one side, the "classic" Twilight, on the other - literally, one only has to flip the book -Life and Death $^{82}$. Life and Death and Twilight tell the same story, follow the same plot, and even use the same words. However, in Life and Death, characters' genders are reversed: Bella, the human girl in love with the dangerous Edward, becomes Beau, a timid human boy falling in love with the frightening vampire called Edythe. This editorial choice would be unthinkable ten years ago $^{83}$.

37 As subversion, agency attribution does not necessarily entail a radical critique of gender norms. However, more than subversion, agency attribution to female characters overtly challenges, at least in part, normative femininity. Once again, the challenge is constructed in opposition to the norm and always runs the risk of reproducing the same norm it tries to question. However, if, with Butler, we take the constituted character of the subject to be the very precondition of its agency ${ }^{84}$, and if children's literature, with its characters provided with strong constituted subjectivities, overtly stages how the constitution of a subject works, then questioning how agency is attributed to these female protagonists is particularly interesting and critically relevant :

Femininity is thus not the product of a choice, but the forcible citation of a norm, one whose complex historicity is indissociable from relations of discipline, regulation, punishment. Indeed, there is no 'one' who takes on a gender norm. On the contrary, this citation of the gender norm is necessary in order to qualify as a 'one,' to become viable as a 'one,' where subject-formation is dependent on the prior operation of legitimating gender norms ${ }^{85}$.

Both subversion and agency attribution generally work in order to question normative femininity, to provide other frameworks in order to become viable as one. However, normative femininity is just one effect produced by gender norms. Moreover, femininity, 
as an effect of power, is always normative. Indeed, even if Katnis, Tris and Tally's femininity succeeds in challenging more traditional ideas of femininity, it persists in being exclusionary, as every identity category is ${ }^{86}$.

The third narrative strategy children's books seem to construct in order to question gender norms is the representation of non-normative desires. In Butler's terms, desire is a foundational category produced by a specific formation of power ${ }^{87}$. To expose these foundational categories as effect of a specific formation of power, Butler, through Foucault's genealogical critique, investigates

[...] the political stakes in designating as an origin and cause those identity categories that are in fact the effects of institutions, practices, discourses with multiple and diffuse points of origin. The task of this inquiry is to center on - and decenter - such defining institutions: phallologocentrism and compulsory heterosexuality ${ }^{88}$.

Desire is, then, always connected with norms. Norms, however, do not act within a causal framework, they "tend to arrive in clusters, interconnected ${ }^{89}$." Moreover :

Norms act on us from all sides, that is, in multiple and sometimes contradictory ways ; they act upon a sensibility at the same time that they form it ; they lead us to feel in certain ways, and those feelings can enter into our thinking even, as we might well end up thinking about them. They condition and form us, and yet they are hardly finished with that work once we start to emerge as thinking and speaking beings. Rather, they continue to act according to an iterative logic that ends for any of us only when life ends, though the life of norms, of discourse more generally, continues on with a tenacity that is quite indifferent to our finitude ${ }^{90}$.

As Butler argues, norms are pervasive. That is why, especially within a literature conceived as teaching children how to be child-like, the representation of desires and of non-normative desires establishes how gender norms work in configuring what can be desired and what cannot. Non-normative desires represented in children's books are often narrated and staged as troubled : usually, there is a character desiring something or someone he or she is not supposed to desire ; someone - sometimes the character him/ herself -makes it difficult for this desire to be acknowledged; the story comes to a resolution when the main character accepts his/her desire and his/her "true" self.

Non-normative desires can be the desire of a young boy, Alberto (Una bambola per Alberto ${ }^{91}$ ), desperately longing for a doll. This would not be a problem, if he were a girl. But he is not, and everyone makes fun of him and of his queer wish. Luckily, Alberto's grandmother is not at all interested in what other people think of her grandson's tastes when it comes to toys. The trouble caused within the text by Alberto's non-normative desire depends on the disruption of normative masculinity his desire may imply. As Butler claims,

[...] gender norms operate by requiring the embodiment of certain ideals of femininity and masculinity, ones that are almost always related to the idealization of the heterosexual bond. In this sense, the initiatory performative, "It's a girl!" anticipates the eventual arrival of the sanction, "I pronounce you man and wife"92. If "It's a girl!" is performative and anticipates the sanction "I pronounce you man and wife," Alberto's desire, on the contrary, blocks the anticipatory sanction disregarding what it means for a boy to be a boy, and, in so doing, it troubles masculine normativity.

In her 1990 preface to Gender Trouble, Judith Butler asks :

[...] what configuration of power constructs the subject and the Other, the binary opposition between "men" and "woman," and the internal stability of those terms? 
[...] Are those terms untroubling only to the extent that they confirm to a heterosexual matrix for conceptualizing gender and desire $?^{93}$ their external appearances may suggest. Both girls struggle to make their identities
visible, and to reproduce feminine normativity in order to be acknowledged as girls, George as Melissa, Liam as Luna. In Flanagan's perspective,

Depictions of transgendered subjectivity in adolescent fiction address the critical opportunities provided by cross-dressing behaviour, but at the same time acknowledge the contemporary reality of transgender experience. The convergence of cross-dressing representations (i.e., cross-dressing as a critical strategy and cross-dressing as social reality) produces a rich and complex construction of crossdressing subjectivity that addresses both the theoretical and the practical consequences of gender non-conformity ${ }^{102}$.

These are only a few of the stories contemporary children's literature tells its readers. They all raise gender matters, and they do it explicitly because of the fundamental role gender norms play in establishing who has the right to be acknowledged as a human being $^{103}$. Of course, each of the chosen examples raises specific issues and is worth analysing in detail. However, my main aim in considering these texts is to provide an overview of how gender matters are a fundamental part of children's literature, whether it questions gender normativity and the binarism it implies, or it reinforces and reproduces masculine and feminine normativity.

Throughout the essay I have maintained that gender is a fundamental category to understand children's literature and what it does. However, in order to make this 
category actually productive, let me make some brief clarifications with regard to gender norms and children's literature in order to include gender issues in a broader system of power dynamics.

Firstly, since children's literature, as it is conceived, represents its characters as having strong identities and well-defined, "natural," "authentic" subjectivities, it is unlikely to question gender norms radically : the idea of an "I" and of a "self" preceding one's own body, language and existence can be found even in Ognigiorno, Levithan's novel where A. ( Ognigiorno ${ }^{104}$ ), who is neither a girl nor a boy, neither gay nor straight, neither white, nor black, and so on, wakes up every day in a different body. Sometimes she is a girl, sometimes he is a boy, sometimes A. feels as if he/she matches his/her own body, sometimes s/he does not: "Non mi pensavo come un ragazzo o una ragazza; non l'ho mai fatto. Mi limitavo a pensare a me stesso come ragazzo o come ragazza per un giorno. Era come indossare abiti diversi"105. But still, despite his/her queer existence, A. has a strong, neat subjectivity. Moreover, A.'s lives and experiences persist in being materialized within a binary framework.

Secondly, the presence of strong female characters and subversions of models of identity do not necessarily imply a critique to gender norms. Moreover, gender norms regulating bodies' materialization and identity formations are always exclusionary. And lastly, gender norms are just one of the ways in which normativity may act in determining who is granted the right to be acknowledged as a human being, and who is not.

The need to question constantly all kinds of exclusions that we enact and the awareness that there will always be something that is left out is a lesson feminist theories have taught. Butler's notion of performativity allows us to question how materialization practices matter and the effects of naturalness, origin, inevitability they produce; how childhood is materialized through these practices of which children's literature is part and why responsibility is inevitably involved in these processes of mattering. Relevant questions concern, once again, who is excluded, marginalised, not acknowledged as a human being. Within a literature understood as teaching children how to be child-like, Melissa, Luna, A., Trevor, and Tris are important because they make their existences (their language, their desires, their behaviours) conceivable.

By way of conclusion, let me quote Butler in the (perhaps too romantic) belief that, if children's literature does something, this something is to be found in the reconfiguration of what is thought to be conceivable: "Fantasy is what allows us to imagine ourselves and others otherwise; it establishes the possible in excess of the real; it points elsewhere, and when it is embodied, it brings the elsewhere home ${ }^{106}$."

\section{BIBLIOGRAPHY}

Sergia Adamo, ed., Culture planetarie ? Prospettive e limiti della teoria e della critica culturale, Roma, Meltemi Editore, 2007.

Nicolò Ammaniti, I'm Not Scared, trans. Jonathan Hunt, Edinburgh, Canongate, 2003. 
-_-, Io non ho paura, Torino, Einaudi, 2001.

Anna Ascenzi, Dorena Caroli, Luigiaurelio Pomante, Roberto Sani, "History of Education and Children's Literature in the Italian Universities (1988- 2013)," History of Education \& Children's Literature, 9.2 (2014), pp. 825-831.

Derek Attridge, J. M. Coetzee and the Ethics of Reading : Literature in the Event, Chicago - London, University of Chicago Press, 2004.

--_, The Singularity of Literature, London, New York, Routledge, 2004.

Karen Barad, Meeting the Universe Halfway. Quantum Physics and the Entanglement of Matter and Meaning, Durham - London, Duke University Press, 2007.

Sandra L. Beckett, Crossover Fiction : Global and Historical Perspectives, London, New York, Routledge, 2009.

Emy Beseghi, Giorgia Grilli, eds., La letteratura invisibile. Infanzia e libri per bambini, Roma, Carocci, 2011.

Lorenza Biava, Giovanni Peresson, Elena Vergine, Quaderni del giornale della libreria, $\beta$. Leggere in futuro. Rapporto sull'editoria per ragazzi 2013, Milano, AIE, 2013.

Silvia Blezza Picherle, Libri bambini ragazzi. Momenti di evoluzione, Verona, Libreria Editrice Universitaria, 2002.

Pino Boero, Carmine De Luca, La letteratura per l'infanzia, Roma, Bari, Laterza, 2009.

Judith Butler, Bodies that Matter, London, New York, Routledge, 1993.

--C, "Contingent Foundations : Feminism and the Question of Postmodernism", Joan W. Scott, ed., Feminists Theorize the Political, London, New York, Routledge, 1992, pp. 3-21.

---, Gender Trouble, London, New York, Routledge, 2008 (1990').

-- - "Performative Acts and Gender Constitution. An Essay in Phenomenology and Feminist Theory", Theatre Journal 40 (1988), pp. 519-531.

-—-, Senses of the Subject, New York, Fordham University Press, 2015.

---, Undoing Gender, London, New York, Routledge, 2004.

Giorgia Carta, "The Other Half of the Story : The Interaction between Indigenous and Translated Literature for Children in Italy", University of Warwick, 2012 (http://

wrap.warwick.ac.uk/50279/1/WRAP_THESIS_Carta_2012.pdf).

Cristina Chiperi, My dilemma is you. vol. 1, Roma, Leggereditore, 2016.

Beverly Lyon Clark, Margaret R. Higonnet,Girls, Boys, Books, Toys. Gender in Children's Literature and Culture, Baltimore, London, The Johns Hopkins University Press, 1999.

Beverly Lyon Clark, Kiddie Lit : The Cultural Construction of Children's Literature in America, Baltimore, John Hopkins University Press, 2003.

Tricia Clasen, Holly Hassel, ed., Gender(ed) Identities : Critical Rereadings of Gender in Children's and Young Adult Literature, London, New York, Routledge, 2017.

Mariella Colin, “Children's Literature in France and Italy in the Nineteenth Century : Influences and Exchanges", Maria Nikolajeva, ed., Aspects and Issues in the History of Children's Literature, Westport, Greenwood, 1995, pp. 77-87. 
Suzanne Collins, Hunger games. La trilogia, trans. Fabio Parrachini, Simona Brogli, Milano, Mondadori, 2015.

Sonia Elisabetta Corvaglia, Le farfalle indiscrete, Trieste, Einaudi Ragazzi (EL), 2014.

Jonathan Culler, Literary Theory. A Very Short Introduction, Oxford, Oxford University Press, 1997.

Michael Ende, Momo, Torino, trans. Daria Angeleri SEI - Società Editrice Internazionale, 2015.

Ian Falconer, Olivia e le principesse, trans. Barbara Ponti Milano, Nord-Sud, 2013.

Victoria Flanagan, “Gender Studies”, David Rudd, ed., The Routledge Companion to Children's

Literature, London, New York, Routledge, 2010, pp. 26-38.

-- , Into the Closet. Cross-Dressing and the Gendered Body in Children's Literature and Film, London, New York, Routledge, 2011.

Alison Flood, “Study Finds Huge Gender Imbalance in Children's Literature," The Guardian, 6 May 2011, https://www.theguardian.com/books/2011/may/06/gender-imbalance-children-sliterature, last accessed : 7 Jan. 2017.

Elizabeth Flynn, A. Patrocinio Schweickart, Gender and Reading. Essays on Readers, Texts, and Contexts, Baltimore, London, Johns Hopkins University Press, 1986.

Alex Gino, George, trans. Matteo Colombo Milano, Mondadori, 2015.

Marianna Ginocchietti, Giulia Zanfabro, "What Do We Do with Words ? Framing What Is at Stake in Dealing with Literature", Andrea Selleri, Philip Gaydon, eds., Literary Studies and the Philosophy of Literature: New Interdisciplinary Directions, Cham, Palgrave Macmillan, 2016, pp. 225-42.

Elisabetta Gnone, Olga di carta. Il viaggio straordinario, Milano, Salani, 2015.

Mark Haddon, Lo strano caso del cane ucciso a mezzanotte, Milano, Einaudi Scuola, 2006.

--_, Lo strano caso del cane ucciso a mezzanotte, trans. Paola Novarese.Torino, Einaudi, 2014.

---, The Curious Incident of the Dog in the Night-Time, London, Jonathan Cape, 2003.

_- , The Curious Incident of the Dog in the Night-Time, London, David Fickling, 2003.

Shannon Hale, Dean Hale, LeUyenPham, La principessa in black, trans. Francesca Crescentini Milano, Nord-Sud, 2015.

Peter Hunt, "Introduction : The World of Children's Literature Studies", Understanding Children's Literature, Peter Hunt, ed., London, New York, Routledge, 2002, pp. 1-14.

Kathryn James, Death, Gender and Sexuality in Contemporary Adolescent Literature, London, New York, Routledge, 2009.

Rosemary Ross Johnston, “A Narrative Chronotope”, Roger D. Sell, ed., Children's Literature as Communication, Amsterdam, Philadelphia, John Benjamins Publishing Company, 2002, pp. 137-157.

Diana Wynne Jones, Il castello errante di Howl, trans. Daniela Ventura Ferrara, Kappalab, 2015.

Jacqueline Kelly, Il mondo curioso di Calpurnia, trans. Luisa Agnese Dalla Fontana Milano, Salani, 2015.

Katharine Jones, “Getting Rid of Children's Literature”, The Lion and the Unicorn 30.3, 2006, pp. 287-315.

Murray Knowles, Kirsten Malmkjær, Language and Control in Children's Literature, London, New York, Routledge, 1996. 
Francesca Lazzarato, Valeria Moretti, La fiaba rosa : itinerari di lettura attraverso i romanzi per signorine, Roma, Bulzoni, 1981.

James Lecesne, Trevor, trans. Giordano Aterini Milano, Rizzoli, 2014.

Benjamin Lefebvrd, ed., Textual Transformations in Children's Literature. Adaptations, Translations, Reconsiderations, London, New York, Routledge, 2013.

Seth Lerer, Children's Literature. A Reader's History from Aesop to Harry Potter, Chicago, University of Chicago Press, 2008.

Karín Lesnik-Oberstein, “Essentials : What is Children's Literature ? What is Childhood ?", Peter Hunt, ed., Understanding Children's Literature, cit., pp. 15-29.

---, “Introduction", Karín Lesnik-Oberstein, ed., Children's Literature. New Approaches, Basingstoke, PalgraveMacmillan, 2004, pp. 1-24.

David Levithan, Ogni giorno, trans. Alessandro Mari Milano, Rizzoli, 2013.

Astrid Lindgren, PippiCalzelunghe, trans. Annuska Palme Larussa, Donatella Ziliotto Milano, Salani, 2013.

--—, Ronja, trans. Mona Attmark Fantoni Milano, Mondadori, 2015.

James Loxley, Performativity, London, New York, Routledge, 2007.

Anne Lundin, Constructing the Canon of Children's Literature: Beyond Library Walls and Ivory Towers, New York, Routledge, 2004.

Kerry Mallan, Gender Dilemmas in Children's Fiction, Basingstoke, Palgrave Macmillan, 2009.

Janice McCabe, Emily Fairchild, Liz Grauerholz, Bernice A. Pescosolido, Daniel Tope, "Gender in Twentieth-Century Children's Books : Patterns of Disparity in Titles and Central Characters", Gender \& Society 25.2, 2011, pp. 197-226.

Robyn McCallum, Ideologies of Identity in Adolescent Fiction. The Dialogic Construction of Subjectivity, London, New York, Routledge, 1999.

Irene Costera Meijer, Baukje Prins, "How Bodies Come to Matter : An Interview with Judith Butler", Signs, 33.1, 1998, pp. 275-286.

Stepehnie Meyer, Twilight/Life and Death (EdizioneSpecialeDecimoAnniversario), Roma, Fazi Editore, 2016.

--_, Twilight Tenth Anniversary/Life and Death Dual Edition, New York, Little, Brown Books for Young Readers, 2015.

Karin Michaëlis, Bibi. Una bambina del nord, trans. Eva Kampmann Milano, Salani, 2014.

Robert Munsch, La principessa e il drago, ill. Michael Martchenko ; trans. Isabella Maria, Torino, Giralangolo, 2014.

Maria Nikolajeva, “The Dilemma of Children's Literature”, Roger D. Sell, ed., Children's Literature as Communication, Amsterdam, Philadelphia, John Benjamins Publishing Company, 2002, pp. 111-136.

Angelo Nobile, Daniele Giancane, Carlo Marini, Letteratura per L'infanzia e L'adolescenza, Brescia, La Scuola, 2011.

Perry Nodelman, "Decoding the Images : Illustration and Picture Books", Peter Hunt, ed., Understanding Children's Literature, cit., pp. 69-80. 
-—-, The Hidden Adult : Defining Children's Literature, Baltimore, Johns Hopkins University Press, 2008.

Cristina Obber, L'altra parte di me, Milano, Piemme, 2014.

Riitta Oittinen, Translating for Children, New York, Garland, 2000.

Giovanni Peresson, Rapporto sullo stato dell'editoria in Italia 2015, Milano, Associazione Italiana Editori e Edisersrl, 2015.

Julie Anne Peters, Between Mom and Jo, New York, Little Brown and Company, 2006.

--_, Luna, trans. Sara Reggiani Firenze - Milano, Giunti, 2010.

--_, Tra mamma e Jo, trans. Carlotta Scarlata Roma, Playground, 2008.

Bianca Pitzorno, Extraterrestre Alla Pari, Trieste, Einaudi Ragazzi, 2003.

Gill Plain, Susan Sellers, ed., A History of Feminist Literary Criticism, New York, Cambridge University Press, 2007.

Tison Pugh, Innocence, Heterosexuality, and The Queerness of Children's Literature, London, New York, Routledge, 2011.

Philip Pullman, Queste oscure materie. La trilogia (La bussola d'oro; La lama sottile; Il cannocchiale d'ambra), trans. Marina Astrologo, Alfredo Tutimo, Franncesco Brumo Milano, Salani, 2008.

Veronica Roth, Divergent saga : Divergent-Insurgent-Allegiant-Four, trans. Manuela Visintin, Roberta Verde Novara, De Agostini, 2015.

Jacqueline Rose, The Case of Peter Pan or The Impossibility of Children's Fiction, Philadelphia, University of Pennsylvania Press, 1993.

David Rudd, "Theorising and Theories : The Conditions of Possibility of Children's Literature," International Companion Encyclopaedia of Children's Literature, Peter Hunt, ed., London, New York, Routledge, 2004, pp. 29-43.

Katherine Rundell, Sophie sui tetti di Parigi, trans. Mara Pace Milano, Rizzoli, 2015.

Sabrynex, Over : Un'overdose di te, Milano, Rizzoli, 2016.

Charles Sarland, “The Impossibility of Innocence : Ideology, Politics, and Children's Literature,"Peter Hunt, ed., Understanding Children's Literature, pp. 39-55.

Janneke Schotveld, La nonna in fuga, trans. Anna Patruccio Becchi Milano, Lo Stampatello, 2015.

Roberta Seelinger Trites, Waking Sleeping Beauty : Feminist Voices in Children's Novels, Iowa, University of Iowa Press, 1997.

Andrea Selleri, Gaydon, Philip, ed., Literary Studies and the Philosophy of Literature. New Interdisciplinary Directions, Cham, Palgrave Macmillan, 2016.

John Stephens, Language and Ideology in Children's Fiction, London, New York, Longman, 1992.

John Stephens, Robyn McCallum, Retelling Stories, Framing Culture. Traditional Story and Metanarratives in Children's Literature, London, New York, Garland Publishing, 1998.

Anna Todd, After, trans. Ilaria Katerinov Milano, Sperling \& Kupfer, 2015.

Deborah Thacker, "Disdain or Ignorance ? Literary Theory and the Absence of Children's Literature," The Lion and the Unicorn, 24.1, 2000, pp. 1-17.

Deborah Thacker, Jean Webb, Introducing Children's Literature. From Romanticism to Postmodernism, London, New York, Routledge, 2002. 
Adela Turin, Rosaconfetto e altrestorie, Firenze, Motta Junior, 2009.

Scott Westerfeld, Beauty. La trilogia (Brutti ; Perfetti ; Speciali), trans. Angela Ragusa, Maria Bastanzetti, Giorgio Salvi, Milano, Mondadori, 2013.

Jack Zipes, Sticks and Stones: The Troublesome Success of Children's Literature from Slovenly Peter to Harry Potter, London, New York, Routledge, 2002.

Charlotte Zolotow, Clothilde Delacroix, Una bambola per Alberto, trans. Isabella Maria Milano, Giralangolo, 2014.

Joseph L. Zornado, Inventing the Child : Culture, Ideology, and the Story of Childhood, New York, Garland, 2001.

\section{NOTES}

2. The article is part of the broader research I have developed in my $\mathrm{PhD}$ thesis (Letteratura giovanile: questioni di critica, questioni di genere - defended on 29th April 2016).

1. “'It's a possibility,' said Sophie. She said it quietly, so the others wouldn't hear. 'You should never ignore a possibility."' (translations will be provided in footnotes ; they do not refer to any original texts). In the following essay, I make reference to some children's and young adult books currently published in Italy. Having focused on the Italian publishing market means that I have had to deal with texts published in Italian by Italian publishing houses, whether or not these texts were originally written in Italian: I do not consider the original language of these texts to be relevant, unless the linguistic origin may cast light on some significant differences in the transition from one linguistic context to another. However, focusing on a national market does not entail erasing the global dimension of contemporary children's literature: children's literature is a global affair and the Italian publishing market is strictly dependent on the international market of which it is a part (for an overview of the contemporary Italian publishing market see Giovanni Peresson, Rapporto sullo stato dell'editoria in Italia 2015, Milano, AIE e Edisersrl, 2015; for some data on children's books market see Lorenza Biava, Giovanni Peresson, Elena Vergine, Quaderni del giornale della libreria, $\beta$. Leggere in futuro. Rapporto sull'editoria per ragazzi 2013, Milano, AIE, 2013). In this article, I take into account exclusively works of fiction. Although other forms of children's literature (encyclopaedias, colouring books, scientific divulgation books...) are to be considered as children's literature, I do not consider them here.

3. Elizabeth A. Flynn and Patrocinio Schweickart, Gender and Reading. Essays on Readers, Texts, and Contexts, Baltimore - London, Johns Hopkins University Press, 1986, p. xxi.

4. Victoria Flanagan, "Gender Studies," David Rudd, ed., The Routledge Companion to Children's Literature, London, New York, Routledge, 2010, p. 26.

5. Ibid.

6. Ibid.

7. Ibid, p. 37.

8. As far as gender matters and children's literature are concerned, see Beverly Lyon Clark, Margaret R. Higonnet, ed., Girls, Boys, Books, Toys. Gender in Children's Literature and Culture, Baltimore - London, The John Hopkins University Press, 1999; Victoria Flanagan, Into the Closet. Cross-Dressing and the Gendered Body in Children's Literature and Film, London, New York, Routledge, 2011; Victoria Flanagan, “Gender Studies,"op. cit.; Kerry Mallan, Gender Dilemmas in Children's Fiction, Basingstoke, Palgrave Macmillan, 2009; Kathryn James, Death, Gender and Sexuality in Contemporary Adolescent Literature, London - New York, Routledge, 2009; Tison Pugh, Innocence, Heterosexuality, and The Queerness of Children's Literature, London, New York, Routledge, 2011; Roberta Seelinger Trites, Waking Sleeping Beauty: Feminist Voices in Children's Novels, Iowa, 
University of Iowa Press, 1997. In 2017 Routledge Children's Literature and Culture series will publish a new collection on gender(ed) identities: Tricia Clasen, Holly Hassel, ed., Gender(ed) Identities: Critical Rereadings of Gender in Children's and Young Adult Literature, London, New York, Routledge, 2017.

9. Teoria e Storia della Letteratura per l'Infanzia, Letteratura per l'infanzia and Storia della Letteratura Giovanile are identified by the scientific disciplinary sector M-PED/02, which individuates "pedagogy." See Anna Ascenzi et al., "History of Education and Children's Literature in the Italian Universities (1988-2013)," History of Education \& Children's Literature, 9.2 (2014), p. 827.

10. See Giorgia Carta, The Other Half of the Story: The Interaction Between Indigenous and Translated Literature for Children in Italy (PhD Thesis), University of Warwick, 2012. Academia's "slowness" "to integrate children's books into the body of literature" (Anne Lundin, Constructing the Canon of Children's Literature: Beyond Library Walls and Ivory Towers, New York: Routledge, 2004, p. 108) is not an Italian peculiarity. See also Beverly Lyon Clark, Kiddie Lit: The Cultural Construction of Children's Literature in America, Baltimore, John Hopkins University Press, 2003; Karín Lesnik-Oberstein, "Essentials: What is Children's Literature? What is Childhood?", Peter Hunt, ed., Understanding Children's Literature, London, New York, Routledge, 2002; Karín Lesnik-Oberstein, "Introduction", Karín Lesnik-Oberstein, ed., Children's Literature. New Approaches, Basingstoke, Palgrave Macmillan, 2004, pp. 1-24; Murray Knowles, Kirsten Malmkjaer, Language and Control in Children's Literature, London, New York, Routledge, 1996.

11. The exceptions concern criticism on the history of children's literature. See, e.g., Pino Boero, Carmine De Luca, La letteratura per l'infanzia, Roma - Bari, Laterza, 2009; Mariella Colin, "Children's Literature in France and Italy in the Nineteenth Century: Influences and Exchanges," Maria Nikolajeva, ed., Aspects and Issues in the History of Children's Literature, Westport, Greenwood, 1995, pp. 77-87.

12. See «Leggere Senza Stereotipi», Scosse, http://www.scosse.org/leggere-senza-stereotipi/ (last accessed 28/6/2016). Though the list of books edited by Scosse is aimed at questioning all kinds of gender stereotypes and therefore crosses over the limits of binarism, the perspective endorsed by the association is educational rather than literary.

13. Deborah Thacker, "Disdain or Ignorance? Literary Theory and the Absence of Children's Literature", The Lion and the Unicorn, 24.1 (2000), p. 7.

14. See, e.g., Benjamin Lefebvre, ed., Textual Transformations in Children's Literature. Adaptations, Translations, Reconsiderations., London, New York, Routledge, 2013; John Stephens, Robyn McCallum, Retelling Stories, Framing Culture. Traditional Story and Metanarratives in Children's Literature, London, New York, Garland Publishing, 1998.

15. Jonathan Culler, Literary Theory. A Very Short Introduction, Oxford, Oxford University Press, 1997, p. 14.

16. Ibid., p. 15.

17. Ibid.

18. The marginality of children's literature - and of its criticism - within the broader literary system strongly depends on the subaltern position of its readership. For a broader understanding of this dynamics see Giorgia Carta, op. cit.; Beseghi and Grilli considers children's literature to be "invisible" for Italian literary criticism (see Emy Beseghi, Giorgia Grilli, ed., La letteratura invisibile. Infanzia e libri per bambini, Roma, Carocci, 2011.

19. Karín Lesnik-Oberstein, “Essentials: What is Children's Literature? What is Childhood?", op. cit

20. Perry Nodelman, The Hidden Adult: Defining Children's Literature, Baltimore, Johns Hopkins University Press, 2008.

21. Young Adult literature is children's literature. Although some differences do exist, they are not significant enough for YA Fiction not to be considered as part of children's literature (see, 
e.g., above and Sandra L. Beckett, Crossover Fiction: Global and Historical Perspectives, London, New York, Routledge, 2009).

22. Nodelman, The Hidden Adult, op. cit., p. 97.

23. Karín Lesnik-Oberstein, “Essentials: What is Children's Literature? What is Childhood?”, op. cit., p. 15.

24. E.g. Tra mamma e Jo was published for young adults in the United States while, in Italy, it is published in a series for adults. Lo stranocaso del cane ucciso a mezzanotte was published in two different editions, one for young adults, the other one for adults, both in the United States and in the United Kingdom, while, in Italy, the novel is published by Einaudi and Einaudi Scuola (which produces scholastic editions and not young adults' fiction). The same happens even if the crossing is made from the Italian context into the English one: see, e.g., Io non ho paura.

25. For an understanding of children's literature as an institution see also David Rudd, “Theorising and Theories: The Conditions of Possibility of Children's Literature," Peter Hunt, ed., International Companion Encyclopaedia of Children's Literature, London, New York, Routledge, 2004, pp. 29-43; Seth Lerer, Children's Literature. A Reader's History from Aesop to Harry Potter, Chicago, University of Chicago Press, 2008; Peter Hunt, ed., Understanding Children's Literature, London, New York, Routledge, 2002; Pino Boero, Carmine De Luca, op. cit.).

26. Not only children's literature, but literature itself is an institution and, as such, it is defined by processes of canonisation and by discourses on what literature is (or should to be): "[although] within a given culture at a given time there will be a certain body of works that are widely received as literary, the slightest acquaintance with literary history shows that it is a far from stable category" (Derek Attridge, The Singularity of Literature, London - New York, Routledge, 2004, p. 61). See Ginocchietti, Marianna and Giulia Zanfabro, "What Do We Do with Words? Framing What Is at Stake in Dealing with Literature," in Literary Studies and the Philosophy of Literature: New Interdisciplinary Directions. Ed. Andrea Selleri and Philip Gaydon, Cham, Palgrave Macmillan, 2016, pp. 225-242.

27. See also Karín Lesnik-Oberstein, "Essentials: What is Children's Literature? What is Childhood?", op. cit.; Perry Nodelman, The Hidden Adult, op. cit.; Charles Sarland, "The Impossibility of Innocence: Ideology, Politics, and Children's Literature," in Peter Hunt, ed., Understanding Children's Literature, op. cit., pp. 39-55; Rosemary Ross Johnston, “A Narrative Chronotope," Roger D. Sell, ed., Children's Literature as Communication, Amsterdam - Philadelphia, John Benjamins Publishing Company, 2002, pp. 137-157; Beverly Lyon Clark, “Audience”, Lissa Paul Philip Nel, ed., Keywords for Children's Literature, New York, New York University Press, 2011, pp. 14-16; Maria Nikolajeva, “The Dilemma of Children's Literature”, Roger D. Sell, ed., Children's Literature as Communication, Amsterdam - Philadelphia, John Benjamins Publishing Company, 2002, pp. 111-136; Riitta Oittinen, Translating for Children, New York, Garland, 2000; Murray Knowles, Kirsten Malmkjær, op. cit; Deborah Thacker, Jean Webb, Introducing Children's Literature. From Romanticism to Postmodernism, London, New York, Routledge, 2002; Jacqueline Rose, The Case of Peter Pan or The Impossibility of Children's Fiction, Philadelphia, University of Pennsylvania Press, 1993; Jack Zipes, Sticks and Stones: The Troublesome Success of Children's Literature from Slovenly Peter to Harry Potter, London, New York, Routledge, 2002.

28. E.g. Rosemary Ross Johnston, op. cit.; Maria Nikolajeva, op. cit.; Nodelman, The Hidden Adult, op. cit.; Riitta Oittinen, op. cit.; Charles Sarland, op. cit.; Jack Zipes, op. cit.

29. As far as young adults are concerned, this exclusion has started to weaken (see the global success of Anna Todd, After, Milano, Sperling \& Kupfer, 2015 or of its Italian versions: Cristina Chiperi, My dilemma is you. Vol. 1, Roma, Leggereditore, 2016 and Sabrynex, Over: Un'overdose di te, Milano, Rizzoli, 2016 and of self-publishing platforms as wattpad); however the existence of these teenage authors within children's literature is an exception rather than a rule.

30. Perry Nodelman, The Hidden Adult, op. cit., p. 5. 
31. Childhood, not children. I am not making reference here to real children, nor to real child readers. I am interested in the ideas of childhood children's literature and its criticism imply and in how literature, as it is conceived, plays a pivotal role in shaping these ideas. For a broader analysis of how children's literature critics, even those she calls "book people", are often "unable to escape relaying on the existence of a 'real' child" see Karìn Lesnik-Oberstein, Children's Literature: Criticism and the Fictional Child, Basingstoke, Palgrave Macmillan, 1994, and the other more recent works by the author cited in this essay. There is a crucial difference between critics presupposing the existence of a real, authentic child (see Silvia Blezza Picherle, Libri bambini ragazzi. Momenti di evoluzione, Verona, Libreria Editrice Universitaria, 2002; Emy Beseghi, GiorgiaGrilli, "Introduzione," Emy Beseghi, Giorgia Grilli, ed., op. cit., pp. 11-19.; Angelo Nobile, Daniele Giancane, Carlo Marini, Letteratura per l'infanzia e l'adolescenza, Brescia, La Scuola, 2011), and those who question the existence of the child, pointing out the fictionality of childhood (children do exist, but what we mean by childhood is contingent, see Karín Lesnik-Oberstein, "Essentials: What is Children's Literature? What is Childhood?", op. cit.; Jacqueline Rose, op. cit.; Joseph L. Zornado, Inventing the Child: Culture, Ideology, and the Story of Childhood, New York, Garland, 2001; Jack Zipes, op. cit.; Katharine Jones, “Getting Rid of Children's Literature," The Lion and the Unicorn, 30. 3 (2006), pp. 287-315; Robyn McCallum, Ideologies of Identity in Adolescent Fiction. The Dialogic Construction of Subjectivity, London, New York, Routledge, 1999; Peter Hunt, "Introduction: The World of Children's Literature Studies", Peter Hunt (ed.) Understanding Children's Literature, op. cit., pp. 1-14.).

32. Tison Pugh, op. cit., p. 3.

33. Karín Lesnik-Oberstein, "Essentials: What is Children's Literature? What is Childhood?", op. cit., p. 16.

34. Perry Nodelman, The Hidden Adult, op. cit., p. 167.

35. Robyn McCallum, op. cit.

36. John Stephens, Language and Ideology in Children's Fiction, London, New York, Longman, 1992.

37. McCallum, op. cit., p. 4.

38. Karen Barad, op. cit, p. 46.

39. Ibid.

40. For a broader understanding of the notion of performativity within different disciplines and from different perspectives see James Loxley, Performativity, London, New York: Routledge, 2007.

41. Karen Barad, op. cit., p. 89.

42. Ibid., p. 90.

43. In Meeting the Universe Halfway, Barad proposes a notion of performativity slightly different from Butler's, even if she acknowledges the importance of Butler's theorisation in her own understanding of performativity. In Barad's view, Butler's notion of performativity fails in providing "an adequate account between discursive practices and material phenomena" (ibid., p. 146). On the contrary, Barad proposes "a posthumanist performative approach to understanding technoscientific and other naturalcultural (sic) practices that specifically acknowledges and takes account of matter's dynamism" (ibid., p. 135). As far as this essay is concerned, the claimed difference between the two notions of performativity is not meaningful. Moreover, Barad's essay is particularly complex and its analysis would bring me too far from the aims of this article. Nonetheless, I take Barad's perspective to be particularly relevant since it questions representationalism from a physicist perspective.

44. See Joseph L. Zornado, op. cit.

45. By effects of naturalness, origin and inevitability I mean the result of those discursive practices that, once they have been iterated, produce an illusion of naturalness on gender and on those features that are ascribed to childhood as "natural". Judith Butler has analysed the effect of naturalness in relation to gender in Judith Butler, Gender Trouble, London - New York, Routledge, 
2008 (1990'); Judith Butler, Bodies that Matter, London - New York, Routledge, 1993; Judith Butler, Senses of the Subject, New York, Fordham University Press, 2015, and in other works.

46. Judith Butler, Bodies that Matter, op. cit., p. 2.

47. Ibid.

48. Ibid., pp. 2-3.

49. Gill Plain, Susan Sellers, ed., A History of Feminist Literary Criticism, New York, Cambridge University Press, 2007, p. 1.

50. Mallan, op. cit., p. 3.

51. Judith Butler, "Contingent Foundations: Feminism and the Question of Postmodernism", Joan

W. Scott, ed., Feminists Theorize the Political, London-New York, Routledge, 1992, p. 8.

52. Irene Costera Meijer and Baukje Prins, "How Bodies Come to Matter: An Interview with Judith Butler," Signs, 33.1 (1998), pp. 275-286.

53. See Perry Nodelman, "Decoding the Images: Illustration and Picture Books," Peter Hunt, ed., Understanding Children's Literature, op. cit., p. 77.

54. Mallan, op. cit., p. 3.

55. Joseph L. Zornado, op. cit., p. 14.

56. Mallan, op. cit., p. 3.

57. See Nodelman, The Hidden Adult, op. cit. Nodelman does not formulate the relation in these terms, even though he outlines the link between the learning of gender norms and children's literature.

58. Ibid., p. 173.

59. Clark, Higonnet, ed., op. cit., p. 1.

60. Ibid.

61. See Sergia Adamo, ed., Culture planetarie? Prospettive e limiti della teoria e della critica culturale, Roma, Meltemi Editore, 2007, p. 35.

62. Kerry Mallan, op. cit., p. 14.

63. Victoria Flanagan, “Gender Studies," op. cit., p. 26.

64. See Francesca Lazzarato, Valeria Moretti, La fiaba rosa: itinerari di lettura attraverso i romanzi per signorine, Roma, Bulzoni, 1981.

65. Adela Turin, Rosaconfetto e altre storie, Firenze, Motta Junior, 2009, p. 8 ("pinkcomfit").

66. Turin, op. cit., p. 18.

67. Ibid., p. 38.

68. Bianca Pitzorno, Extraterrestre alla pari, Trieste, Einaudi Ragazzi, 2003.

69. Ibid., p. 12 ("If we do not know if he is a boy or a girl, how are we supposed to treat him? Or her?... damn it! Mo, whatever s/he is!").

70. Ibid., p. 19 ("Mo wasn't an ambiguous and disquieting being, s/he certainly was a boy, or a girl, and very soon they would know, and finally behave accordingly").

71. It is particularly relevant to point out that both Rosaconfetto e altrestorie and Extraterrestre alla pari have been recently re-published in Italy.

72. Ian Falconer, Olivia e le principesse, Milano, Nord-Sud, 2013.

73. Robert Munsch, La principessa e il drago, Torino, Giralangolo, 2014. This book has recently hit the headlines because of a news item involving two parents from Massa Carrara. They have withdrawn their daughter from her school claiming that the reading of La principessa e il drago is not appropriate for young children (see http://www.huffingtonpost.it/2015/10/28/laprincipessa-salva-il-p_n_8408624.html, last accessed 8/7/2016).

74. www.edt.it/aree/giralangolo-sottosopra/, last accessed 30/6/2016.

75. See http://www.toscanaspettacolo.it/19698/liber-tutt/, last accessed 30/6/2016.

76. Shannon Hale et al., La principessa in black, Nord-Sud, 2015, p. 18 ("Princesses do not slide down secret chutes and high-jump castle walls.") 
77. See, e.g., Flood, Alison. "Study Finds Huge Gender Imbalance in Children's Literature", The Guardian, 6 May 2011 (https://www.theguardian.com/books/2011/may/06/gender-imbalancechildren-s-literature, last accessed: 7/2/2017); Janice McCabe, "Gender in Twentieth-Century Children's Books: Patterns of Disparity in Titles and Central Characters", Gender \& Society 25.2 (2011), pp. 197-226.

78. See book series, such as Principesse Favolose, Le sirene, Storie di cavalli, Belle, astute e coraggiose by EL; Valentina e co., Princess college, Scuola di danza by Il Battello a Vapore; or Ragazzine, Il diario di Martina, Gaia by Mondadori. In these series some persistent trends work in producing a specific kind of femininity (pink covers; female characters; animals, diaries, human relations, love and friendship as privileged topics...).

79. Suzanne Collins, Hunger games, La trilogia, Milano, Mondadori, 2015.

80. Veronica Roth, Divergent saga: Divergent-Insurgent-Allegiant-Four, Novara, De Agostini, 2015. As in the case of Hunger Games, each novel of the trilogy has been adapted into a film: on $9^{\text {th }}$ March 2016 the first part of the third episode, Allegiant, was released; the second part of the episode is expected to be released in 2017. As for Harry Potter and Hunger Games, the last episode of the saga has been split into two films.

81. Scott Westerfeld, Beauty. La trilogia (Brutti; Perfetti; Speciali), Milano, Mondadori, 2013.

82. Stephenie Meyer, Twilight Tenth Anniversary/Life and Death Dual Edition, New York, Little, Brown Books for Young Readers, 2015; see also Italian edition: Stephenie Meyer, Twilight/Life and Death (edizione special decimo anniversario), Roma, FaziEditore, 2016.

83. I have made reference to the most known novels portraying strong female characters, however, there are plenty of other cases. See also Janneke Schotveld, La nonna in fuga, Milano, Lo Stampatello, 2015; Karin Michaëlis, Bibi. Una bambina del nord, Milano, Salani, 2014; Pippi Calzelunghe, Milano, Salani, 2013; Ronja, Milano, Mondadori, 2015; Jacqueline Kelly, Il mondo curioso di Calpurnia, Milano, Salani, 2015; Elisabetta Gnone, Olga di carta. Il viaggio straordinario, Milano, Salani, 2015; Michael Ende, Momo, Torino, SEI - Società Editrice Internazionale, 2015; Katherine Rundell, Sophie Sui Tetti Di Parigi, Milano, Rizzoli, 2015; Diana Wynne Jones, Il Castello Errante Di Howl, Ferrara, Kappalab, 2015.

84. Judith Butler, "Contingent Foundations: Feminism and the Question of Postmodernism," op. cit., p. 12.

85. Judith Butler, Bodies that Matter, op. cit., p. 232.

86. Judith Butler, "Contingent Foundations: Feminism and the Question of Postmodernism," op. cit., p. 8.

87. Judith Butler, Gender Trouble, op. cit., p. xxxi.

88. Ibid.

89. Judith Butler, Senses of the Subject, op. cit., p. 5.

90. Ibid.

91. Charlotte Zolotow, Clothilde Delacroix, Una bambola per Alberto, Milano, Giralangolo, 2014 (published in the same series as La principessa e il drago).

92. Judith Butler, Bodies that Matter, op. cit., p. 232.

93. Judith Butler, Gender Trouble, op. cit, p. xxix.

94. James Lecesne, Trevor, Milano, Rizzoli, 2014. Before being a novel, Trevor was a play, a short film (Academy Awards in 1995) and the name of a help line for American LGBTQI teenagers ( http://www.thetrevorproject.org/, last accessed 10/7/2016).

95. Cristina Obber, L'altra parte di me, Milano, Piemme, 2014.

96. James Lecesne, op. cit., p. 62 ("Whether I am gay or not, it doesn't matter [...]. Some of us prefer to be a mystery - even to ourselves - until we are ready.")

97. Victoria Flanagan, “Gender Studies," op. cit., p. 31.

98. Sonia Elisabetta Corvaglia, Le farfalle indiscrete, Trieste, Einaudi Ragazzi (EL), 2014.

99. Ibid., p. 40. 
100. Alex Gino, George, Milano, Mondadori, 2015.

101. Julie Anne Peters, Luna, Firenze-Milano, Giunti, 2010.

102. Victoria Flanagan, Into the Closet, op. cit., pp. 6-7.

103. See Adamo, op. cit., p. 35.

104. David Levithan, Ogni giorno, Milano, Rizzoli, 2013. In the Italian edition, the translator has chosen to inflect adjectives and nouns referring to A. in the masculine form; however, we do not know if A. is a boy or a girl, and A. is probably neither.

105. Ibid., p. 182; “I didn't think of myself as a boy or a girl - I never have. I just thought of myself as a boy or a girl for a day. It was like wearing a different set of clothes".

106. Judith Butler, Undoing Gender, London - New York, Routledge, 2004.

\section{ABSTRACTS}

Despite the fact that "the representation of gendered bodies and behaviours" within children's literature is an issue that is "highly significant" and "frequently addressed, [...] the application of gender studies to children's texts [...] is still very much a work in progress" (Flanagan 2010). In this article, my main aims are, firstly, to argue the importance of children's literature as literature, and secondly, to show why gender does matter within children's literature and its criticism, even within those books not tackling the issue at first glance.

The article ${ }^{2}$ is divided into three sections :

Dilemmas in Children's Literature : Performativity Matters, in which I introduce the perspective on children's literature I endorse, the framework I propose to understand children's literature and show that what it does is performative ;

Gender Dilemmas, in which I claim that gender is a fundamental category to understand children's literature and what it does ;

Subversions, Agency Attributions, Desires: Non-normative Representations, in which I individuate three different narrative strategies children's books may employ in order to question gender norms. Children's literature representations of non-normative behaviours, desires, and agencies make non-normative existences conceivable, and, as such, real.

Bien que la représentation des corps et des comportements de genre soit une question extrêmement significative dans la littérature de jeunesse, l'application des "études de genre" à cette littérature est encore très peu explorée (Flanagan 2010). Cet article se propose de remarquer l'importance de la littérature de jeunesse en tant que littérature et, en même temps, d'élucider les raisons pour lesquelles le genre représente une des questions constitutives des livres pour enfants (même dans ceux qui ne traitent pas ouvertement le sujet) et de la critique qui s'en occupe.

Le présent article est structuré en trois sections. Dans la première section, Dilemmas in Children's Literature : Performativity Matters, nous proposons un cadre théorique performatif pour la compréhension de la littérature de jeunesse et pour la compréhension de son pouvoir performatif. Dans la seconde section, Gender Dilemmas, nous énonçons le concept de genre comme catégorie d'analyse fondamentale pour la littérature de jeunesse. Enfin, dans la troisième section, Subversions, Agency Attributions, Desires: Non-normative Representations, nous identifions trois différentes stratégies narratives que les livres pour enfants mettent en jeu afin de défier les normes de genre. En représentant dans le texte des comportements, des désirs et 
des agencies non normatifs, la littérature de jeunesse rend les existences non normatives imaginables, et, de ce fait, réelles.

\section{AUTHOR}

\section{GIULIA ZANFABRO}

Giulia Zanfabro graduated from the University of Trieste in Italian Literature (BA) with a thesis on La Voce, women and the matter of sexuality, and in Literary Theory (MA) with a thesis on J.M. Coetzee's fiction. She has recently defended her doctoral thesis on children's literature criticism and gender matters. Her dissertation is focused both on matters arising from the analysis of children's literature criticism, and on children's literature and young adult fiction publishing markets. She is also interested in feminist theories, comparative literatures and cultural studies. 